\title{
Smoking Behavior among Female Worker in Indonesia Does Education Matter?
}

\author{
Nikmatur Rohmah ${ }^{1}$, Anita Dewi Prahastuti Sujoso ${ }^{2}$, Masruroh $^{3}$, Ilyas Ibrahim ${ }^{4}$, \\ Qurnia Andayani ${ }^{5}$, Irfansyah Baharuddin Pakki ${ }^{6}$, Agung Dwi Laksono ${ }^{7}$ \\ ${ }^{1}$ Lecturer, Faculty of Health Science, Muhammadiyah University of Jember East Java Indonesia, ${ }^{2}$ Lecturer, \\ Public Health Faculty Jember University East Java, Indonesia, ${ }^{3}$ Lecturer, Faculty of Health Science Universitas \\ Pesantren Tinggi Darul Ulum Jombang,East Java, Indonesia, ${ }^{4}$ Lecturer, Faculty of Health Science, Bumi Hijrah \\ Tidore University, North Maluku, Indonesia, ${ }^{5}$ Doctoral Program, Faculty of Public Health, University of Airlangga \\ Surabaya Indonesia, ${ }^{6}$ Lecturer, Faculty of Public Health University of Mulawarman, Samarinda, Kalimantan \\ Timur, Indonesia, ${ }^{7}$ Researcher, National Institute of Health Research and Development, \\ The Indonesian Ministry of Health
}

\begin{abstract}
Smoking behavior in women has a risk of fertility problems, the reproductive system, and many other health problems. This study was aimed at analyzing the effect of education level on smoking behavior among female workers in Indonesia. The samples used were a female worker. The sample size was 51,815 respondents. Apart from education, other independent variables analyzed were the place of residence, age, marital, wealth, and pregnant status. Determination of determinant by binary logistic regression. The results of the study informed that female workers with primary education were 0.456 times more likely than no education to become smokers. Female workers with secondary education are 0.428 times more likely than no education to become smokers. Female workers with higher education are 0.219 times more likely than no education to become smokers. The results of this analysis indicate that the higher the education level, the lower the possibility of female workers becoming smokers. Apart from the education level, 4 other variables were also found as predictors of smoking behavior among female workers, namely the place of residence, age, wealth, and pregnant status. It was concluded that the education level was a predictor of smoking behavior among female workers in Indonesia. The higher the education level, the lower the possibility of female workers becoming smokers.
\end{abstract}

Keywords: Smoking behavior, female worker, tobacco use.

\section{Introduction}

It is reported that female smokers worldwide reach 250 million people, $22 \%$ in developed countries, and $9 \%$ in developing countries ${ }^{1}$.Several countries reported a complete reversal in relative prevalence between men and women, accompanied by a shrinking gap between male and female smokers in adulthood ${ }^{2}$. This

\footnotetext{
Corresponding Author:

Nikmatur Rohmah

Lecturer, Faculty of Health Science, Muhammadiyah University of Jember East Java Indonesia e-mail: nikmaturrohmah@unmuhjember.ac.id
}

condition shows that smoking behavior in women globally can change significantly in the future ${ }^{2}$. In line with the increase in female smokers, it was found that female smokers were at greater risk of experiencing pain due to tobacco use than men. Female smokers are at risk of developing breast, fibroid, and lung cancer ${ }^{3,4}$. Some female smokers reported not stopping smoking while pregnant ${ }^{5}$. Screening results in female smokers showed positive depression at early pregnancy, late pregnancy, and 12 months after delivery ${ }^{5}$. Quitting smoking especially early in pregnancy is associated with a reduction in preterm birth ${ }^{6}$. Besides, smoking also has adverse effects on the reproductive system, increased risk of infertility, stillbirth, sudden death syndrome, and intrauterine fetal growth disorders ${ }^{7}$. 
Most of the smokers are female workers. Female smokers working in Indonesia are reported to be $66.2 \%{ }^{8}$, in Iran 27.7\% ${ }^{9}$, and Brazil $40.3 \%{ }^{10}$. $7.3 \%$ of female smokers in Brazil still smoke during pregnancy ${ }^{10}$. Women who smoke in China are reported to have poor education and socioeconomic ${ }^{8}$. A Canadian study of female smokers reported that female smokers were more likely to continue smoking during pregnancy which was associated with education and employment status ${ }^{11}$. Meanwhile, in Bangladesh, it was also reported that $51.0 \%$ of smokers were women, and $33.6 \%$ worked in various sectors ${ }^{12}$.

Female workers are one of the seven vulnerable groups. Some of the vulnerabilities of female workers that occur in the European Union include discrimination in workgroups, sexual harassment, lack of concern for reproductive health, including menstruation leave and pregnancy ${ }^{13}$. Vulnerabilities in female reproduction include not being allowed to get pregnant while working, not having a baby during the contract period, greater wage discrimination for men, including work benefits, such as children and family, less than maximum menstrual and pregnancy leave, harassment, and sexual violence ${ }^{14}$. The psychological vulnerability of female workers is $30.8 \%$ higher than that of men. Psychological vulnerabilities can take the form of bullying, anxiety, stress, mental badness, and depression ${ }^{15}$.

Working women show an important aspect in the macro economy ${ }^{16}$,but it is also a challenge that women must face. Working women have a double burden, namely as workers outside the home and workers in the home ${ }^{17}$. World Bank data shows that the percentage of female workers in 2018 was $50.7 \%$, and those aged 15 years and over. This data forms the basis that women have a role in the family economy ${ }^{18}$. The dual roles of female workers include caring for their children, being mothers, partners as well as being members of society. This condition affects emotional health, physical health, social and economic activities ${ }^{15}$. Based on the background description, the study was aimed at analyzing the effect of education level on smoking behavior among female workers in Indonesia.

\section{Materials and Method}

Data from the 2017 Indonesian Demographic Data Survey (IDHS) was used as material for analysis in this study. The unit of analysis in this study was female workers (15-49 years) in Indonesia. The 2017 IDHS used stratification and multistage random sampling, so it got 51,815 respondents.

Smoking behavior is the respondent's recognition of his smoking behavior. Divided into 2 categories, namely no smoking and smoking. Apart from the education level, other independent variables analyzed were the type of place of residence, age groups, marital status, wealth status, and pregnant status.

All variables involved in the analysis of this study were dichotomous variables, therefore the chi-square test was used to examine the relationship between education level and other variables. In the final stage, binary logistic regression is used because of the nature of the dependent variable. All statistical analyzes were carried out using SPSS 22 software.

\section{Results and Discussion}

Table 1 displays descriptive statistics of female workers in Indonesia. It can be seen that all categories of education level are dominated by female workers who don't smoke. Based on the education level, primary and no education female workers are predominantly living in rural areas, while female workers with secondary and higher education levels are predominantly living in urban areas.

Based on the age group, primary and no education female workers are dominated by the 45-49 age group, while female workers with secondary and higher education levels are dominated by the 35-39 age group. All-female workers are dominated by those who are married or living with partners.

Based on wealth status, primary and no education female workers were dominated by the poorest, while female workers who had education at the secondary category level were dominated by the richer, and female workers who had education at the higher category level were dominated by the richest. Based on variable status, all-female workers were dominated by those who were not pregnant.

Table 2 shows the results of the binary logistic regression of smoking behavior among female workers in Indonesia. It can be seen that female workers with primary education have a 0.456 times chance compared to no education female workers to become smokers (OR 0.456; 95\% CI 0.393-0.529). Female workers with secondary education are 0.428 times more likely than 
no education female workers to become smokers (OR $0.428 ; 95 \%$ CI $0.366-0.501$ ). Female workers with higher education are 0.219 times more likely than no education female workers to become smokers (OR 0.219; 95\% CI 0.171-0.279).

The results of this analysis indicate that the higher the education level, the lower the possibility of female workers becoming smokers. The better the level of education, the more female workers understand the risk of behavior that will be adopted in their daily lives. This condition makes education level often found as a positive predictor of output in the health sector ${ }^{8,19,20}$. On the other hand, low levels of education are often found to be a barrier to output in the health sector ${ }^{21,22}$.

Apart from the education level, 4 other variables were also found as predictors of smoking behavior among female workers. First, based on the type of place of residence, it was found that female workers living in rural were 0.643 times more likely than female workers living in urban to become smokers (OR 0.643; 95\% CI 0.588-0.704). This information shows that female workers who live in urban have a higher likelihood of becoming smokers. The same findings were also confirmed in several previous studies ${ }^{23,24}$.

Table 1. The descriptive statistics of the education level of female workers in Indonesia $(n=51,815)$

\begin{tabular}{|c|c|c|c|c|c|c|c|c|c|}
\hline \multirow{3}{*}{ Variables } & \multicolumn{8}{|c|}{ Education Level } & \multirow{3}{*}{$\mathbf{P}$} \\
\hline & \multicolumn{2}{|c|}{ No Education } & \multicolumn{2}{|c|}{ Primary } & \multicolumn{2}{|c|}{ Secondary } & \multicolumn{2}{|c|}{ Higher } & \\
\hline & n & $\%$ & $\mathbf{n}$ & $\%$ & n & $\%$ & $\mathbf{n}$ & $\%$ & \\
\hline Smoking Behavior & & & & & & & & & $* * * 0.000$ \\
\hline No & 2672 & $91.9 \%$ & 31546 & $96.6 \%$ & 40080 & $97.2 \%$ & 9302 & $98.7 \%$ & \\
\hline Yes & 237 & $8.1 \%$ & 1125 & $3.4 \%$ & 1154 & $2.8 \%$ & 123 & $1.3 \%$ & \\
\hline \multicolumn{10}{|l|}{ Type of place of residence } \\
\hline Urban & 575 & $19.7 \%$ & 11233 & $34.4 \%$ & 23219 & $56.3 \%$ & 6300 & $66.8 \%$ & \\
\hline Rural & 2337 & $80.3 \%$ & 21450 & $65.6 \%$ & 18025 & $43.7 \%$ & 3126 & $33.2 \%$ & \\
\hline Age Group & & & & & & & & & $* * * 0.000$ \\
\hline $15-19$ & 7 & $0.2 \%$ & 114 & $0.3 \%$ & 318 & $0.8 \%$ & 6 & $0.1 \%$ & \\
\hline $20-24$ & 45 & $1.5 \%$ & 718 & $2.2 \%$ & 2354 & $5.7 \%$ & 241 & $2.6 \%$ & \\
\hline $25-29$ & 113 & $3.9 \%$ & 2085 & $6.4 \%$ & 4918 & $11.9 \%$ & 1278 & $13.6 \%$ & \\
\hline $30-34$ & 247 & $8.5 \%$ & 4336 & $13.3 \%$ & 7646 & $18.5 \%$ & 2209 & $23.4 \%$ & \\
\hline $35-39$ & 443 & $15.2 \%$ & 7125 & $21.8 \%$ & 9597 & $23.3 \%$ & 2231 & $23.7 \%$ & \\
\hline $40-44$ & 724 & $24.9 \%$ & 8856 & $27.1 \%$ & 9111 & $22.1 \%$ & 1812 & $19.2 \%$ & \\
\hline $45-49$ & 1333 & $45.8 \%$ & 9449 & $28.9 \%$ & 7300 & $17.7 \%$ & 1649 & $17.5 \%$ & \\
\hline Marital Status & & & & & & & & & 0.527 \\
\hline Never in union/Divorced/Widowed & 2 & $0.1 \%$ & 17 & $0.1 \%$ & 27 & $0.1 \%$ & 9 & $0.1 \%$ & \\
\hline Married/Living with partner & 2910 & $99.9 \%$ & 32666 & $99.9 \%$ & 41217 & $99.9 \%$ & 9417 & $99.9 \%$ & \\
\hline Wealth status & & & & & & & & & $* * * 0.000$ \\
\hline Poorest & 2065 & $70.9 \%$ & 13508 & $41.3 \%$ & 7895 & $19.1 \%$ & 547 & $5.8 \%$ & \\
\hline Poorer & 476 & $16.3 \%$ & 7737 & $23.7 \%$ & 7817 & $19.0 \%$ & 803 & $8.5 \%$ & \\
\hline Middle & 220 & $7.6 \%$ & 5801 & $17.7 \%$ & 8458 & $20.5 \%$ & 1088 & $11.5 \%$ & \\
\hline Richer & 102 & $3.5 \%$ & 3916 & $12.0 \%$ & 9134 & $22.1 \%$ & 2019 & $21.4 \%$ & \\
\hline Richest & 49 & $1.7 \%$ & 1721 & $5.3 \%$ & 7940 & $19.3 \%$ & 4969 & $52.7 \%$ & \\
\hline Pregnant & & & & & & & & & $* * * 0.000$ \\
\hline No & 2872 & $98.6 \%$ & 31955 & $97.8 \%$ & 39802 & $96.5 \%$ & 9083 & $96.4 \%$ & \\
\hline Yes & 40 & $1.4 \%$ & 728 & $2.2 \%$ & 1442 & $3.5 \%$ & 343 & $3.6 \%$ & \\
\hline
\end{tabular}

Note: ${ }^{*} \mathrm{p}<0.05 ;{ }^{* *} \mathrm{p}<0.01 ;{ }^{* * *} \mathrm{p}<0.001$. 
Table 2: Results of binary logistic regression of smoking behavior among female worker in Indonesia $(\mathbf{n}=\mathbf{5 1 , 8 1 5 )}$

\begin{tabular}{|c|c|c|c|c|}
\hline \multirow{2}{*}{ Predictor } & \multicolumn{4}{|c|}{ Low Birth Weight } \\
\hline & $\mathbf{P}$ & OR & Lower Bound & Upper Bound \\
\hline Education Level: No education & - & - & - & - \\
\hline Education Level: Primary & $* * * 0.000$ & 0.456 & 0.393 & 0.529 \\
\hline Education Level: Secondary & $* * * 0.000$ & 0.428 & 0.366 & 0.501 \\
\hline Education Level: Higher & $* * * 0.000$ & 0.219 & 0.172 & 0.279 \\
\hline Type of place of residence: Urban & - & - & - & - \\
\hline Type of place of residence: Rural & $* * * 0.000$ & 0.643 & 0.588 & 0.704 \\
\hline Age group of respondents: $15-19$ & - & - & - & - \\
\hline Age group of respondents: $20-24$ & 0.804 & 0.909 & 0.428 & 1.932 \\
\hline Age group of respondents: $25-29$ & 0.531 & 1.258 & .614 & 2.578 \\
\hline Age group of respondents: $30-34$ & 0.137 & 1.712 & .844 & 3.474 \\
\hline Age group of respondents: $35-39$ & $* 0.034$ & 2.140 & 1.057 & 4.330 \\
\hline Age group of respondents: $40-44$ & 0.059 & 1.975 & 0.976 & 3.997 \\
\hline Age group of respondents: $45-49$ & $* 0.032$ & 2.168 & 1.071 & 4.387 \\
\hline Wealth status: Poorest & - & - & - & - \\
\hline Wealth status: Poorer & $* * * 0.000$ & 0.771 & 0.692 & 0.859 \\
\hline Wealth status: Middle & $* * * 0.000$ & 0.523 & 0.460 & 0.595 \\
\hline Wealth status: Richer & $* * * 0.000$ & 0.483 & 0.421 & 0.554 \\
\hline Wealth status: Richest & $* * * 0.000$ & 0.481 & 0.414 & 0.560 \\
\hline Pregnant: No & - & - & - & - \\
\hline Pregnant: Yes & $* 0.028$ & 0.723 & 0.542 & 0.965 \\
\hline
\end{tabular}

Note: ${ }^{*} \mathrm{p}<0.05 ;{ }^{* *} \mathrm{p}<0.01 ;{ }^{* * *} \mathrm{p}<0.001$.

Second, the results of the analysis found that the age group had a partial effect on smoking behavior among female workers. Female workers in the 35-39 age group were 2.140 times more likely than female workers in the 15-19 age group to become smokers (OR 2.140; 95\% CI 1.057-4.330). Female workers in the $45-49$ age group were 2.168 times more likely than female workers in the 15-19 age group to become smokers (OR 2.168; 95\% CI 1.071-4.387). Previous studies in Costa Rica, Iran, and Cuba also informed the same finding, that age is a predictor of smoking behavior ${ }^{23,25,26}$.

Third, wealth status. Female workers with poorer wealth status have a probability of 0.771 times compared to the poorest female workers to become a smoker (OR $0.771 ; 95 \%$ CI 0.692-0.859). Female workers with middle wealth status have a 0.523 times chance compared to the poorest female workers to become smokers (OR
0.523; 95\% CI 0.460-0.595). Female workers with richer wealth status have a 0.483 times chance compared to the poorest female workers to become smokers (OR 0.483 ; 95\% CI 0.421-0.554). The richest female worker was 0.481 times more likely than the poorest female worker to become a smoker (OR $0.481 ; 95 \%$ CI $0.414-$ 0.560 ). This information is in line with the findings of the previous studies ${ }^{27}$.

Fourth, pregnant status. Pregnant female workers had 0.723 times the probability of non-pregnant female workers becoming smokers (OR 0.723 ; 95\% CI $0.542-$ $0.965)$. This means that pregnancy is a protective factor to prevent female workers from smoking.

\section{Conclusions}

Based on the analysis, it can be concluded that education was a predictor of smoking behavior among 
female workers in Indonesia. The higher the education, the lower the possibility of female workers to become smokers. Apart from education, 4 other variables were also found as predictors of smoking behavior among female workers, namely type of place of residence, age group, wealth status, and pregnant status.

Acknowledgments: The author would like to thank the ICF International, who has agreed to allow the 2017 IDHS data to be analyzed in this article.

Source of Funding: Self-funding

Conflict of Interest: The authors declare no conflict of interest, financial or otherwise.

Ethical Clearance: The 2017 IDHS has received ethical clearance from the National Ethics Commission. Utilization of the 2017 IDHS data in this study has been permitted by ICF International through its website: https://dhsprogram.com/data/new-user-registration.cfm.

\section{References}

1. Phetphum C, Pongpreecha B, Hangsantea J, Muankaew W. Predicting Factors for Smoking Behavior among Women Who Frequent Nightlife Entertainment Venues around a University in the Northern Region of Thailand. Subst Abus Res Treat. 2018;12.

2. Solomon A. Gender, women, and the future of tobacco control. Drugs and Alcohol Today. 2020;May:1-15.

3. Jones ME, Schoemaker MJ, Wright LB, Ashworth A, Swerdlow AJ. Smoking and risk of breast cancer in the Generations Study cohort. Breast Cancer Res. 2017;19(1):1-14.

4. Wong JYY, Chang PY, Gold EB, Johnson WO, Lee JS. Environmental tobacco smoke and risk of late-diagnosis incident fibroids in the Study of Women's Health across the Nation (SWAN). Fertil Steril. 2016;106(5):1157-64.

5. Jones AM, Carter-Harris L, Stiffler D, Macy JT, Staten LK, Shieh C. Smoking Status and Symptoms of Depression During and After Pregnancy Among Low-Income Women. JOGNN - J Obstet Gynecol Neonatal Nurs. 2020;49(4):361-72.

6. Soneji $\mathrm{S}$, Beltrán-Sánchez H. Association of Maternal Cigarette Smoking and Smoking Cessation With Preterm Birth. JAMA Netw open. 2019;2(4):1-14.
7. Lukowski A. Women \& Smoking Health risk. 2015.

8. Laksono AD, Wulandari RD, Rukmini R, Matahari R. Determinant of Smoking Behavior among Childbearing Age Women in Indonesia. Int $\mathbf{J}$ Psychosoc Rehabil. 2020;24(8):6292-303.

9. Baheiraei A, Ghafoori F, Nedjat S, Foroushani AR. Sociodemographic characteristics and secondhand smoke exposure among women. Tanaffos. 2013;12(2):41-7.

10. Madeira Domingues RMS, Figueiredo VC, Carmo Leal $\mathrm{M}$ do. Prevalence of pre-gestational and gestational smoking and factors associated with smoking cessation during pregnancy, Brazil, 20112012. PLoS One. 2019;14(5):2011-2.

11. Gilbert NL, Nelson CRM, Greaves L. Smoking Cessation During Pregnancy and Relapse After Childbirth in Canada. J Obstet Gynaecol Canada. 2015;37(1):32-9.

12. Islam FMA, Walton A. Tobacco Smoking and Use of Smokeless Tobacco and Their Association with Psychological Distress and Other Factors in a Rural District in Bangladesh: A Cross-Sectional Study. J Environ Public Health. 2019;2019:11.

13. European Agency for Safety and Health at Work (EU-OSHA). New risks and trends in the safety and health of women at work. Luxembourg: Publications Office of the European Union. Luxembourg; 2014. $51 \mathrm{p}$.

14. Kabir H, Maple M, Fatema SR. Vulnerabilities of Women Workers in the Readymade Garment Sector of Bangladesh : A Case Study of Rana Plaza. J Int Womens Stud. 2018;19(6):224-35.

15. Ansoleaga E, Ahumada M, Cruz AGS. Association of workplace bullying and workplace vulnerability in the psychological distress of chilean workers. Int J Environ Res Public Health. 2019;16(20):1-14.

16. Mehrotra S, Sinha S. Explaining falling female employment during a high growth period. Econ Polit Wkly. 2017;52(39):54-62.

17. Wunrn. Current Trends Suggested Global Strategies to Support the Feminization of the Workforce the Double Burden of Working Women. 2018;

18. Ginting PA. Implementasi Teori Maslow dan Peran Ganda Pekerja Wanita K3L Universitas Padajajaran. Focus J Pekerj Sos. 2019;1(3):220.

19. Wulandari RD, Laksono AD. Education as 
predictor of the knowledge of pregnancy danger signs in Rural Indonesia. Int J Innov Creat Chang. 2020;13(1):1037-51.

20. Ipa $\mathrm{M}$, Widawati $\mathrm{M}$, Laksono $\mathrm{AD}$, Kusrini I, Dhewantara PW. Variation of preventive practices and its association with malaria infection in eastern Indonesia: Findings from community-based survey. PLoS One. 2020;15(5):e0232909.

21. Rohmah N, Yusuf A, Hargono R, Laksono AD, Masruroh, Ibrahim I, et al. Determinants of teenage pregnancy in Indonesia. Indian J Forensic Med Toxicol. 2020;14(3):2080-5.

22. Laksono AD, Wulandari RD. The Barrier to Maternity Care in Rural Indonesia. J Public Heal From Theory to Pract. 2020;Online First.

23. Aguirre AE, Fantin R, Solis CB, Miranda AS. Sociodemographic characteristics associated with the prevalence of tobacco use in Costa Rica. Rev Panam Salud Publica/Pan Am J Public Heal. 2020;44:Article number e17.
24. Barik A, Rai RK, Gorain A, Majumdar S, Chowdhury A. Socio-economic disparities in tobacco consumption in rural India: Evidence from a health and demographic surveillance system. Perspect Public Health. 2016;136(5):278-87.

25. Masjedi MR, Roshanfekr $P$, Naghdi S, Higgs P, Armoon B, Ghaffari S, et al. Socio-economic contributors to current cigarette smoking among Iranian household heads: findings from a national household survey. J Subst Use. 2020;25(2):217-23.

26. Thomson B, Rojas NA, Lacey B, Burrett JA, Varona-Pérez $\mathrm{P}$, Martínez MC, et al. Association of childhood smoking and adult mortality: prospective study of 120000 Cuban adults. Lancet Glob Heal. 2020;8(6):e850-7.

27. Buffarini R, Abdalla S, Weber AM, Costa JC, Menezes AMB, HelenGonçalves, et al. The Intersectionality of Gender and Wealth in Adolescent Health and Behavioral Outcomes in Brazil: The 1993 Pelotas Birth Cohort. J Adolesc Heal. 2020;66(1):S51-7. 